\title{
Economic viability of selling locally grown produce to local restaurants
}

\author{
Amit Sharma, ${ }^{\text {a* }}$ The Pennsylvania State University \\ Catherine Strohbehn, ${ }^{\text {b }}$ Iowa State University \\ Rama B. Radhakrishna, ${ }^{\mathrm{c}}$ The Pennsylvania State University \\ Allan Ortiz, ${ }^{\mathrm{d}}$ University of Costa Rica
}

Submitted 14 February 2012 / Revised 30 April, 3 July and 19 July 2012 / Accepted 27 July 2012 /

Published online 19 December 2012

Citation: Sharma, A., Strohbehn, C., Radhakrishna, R. B., \& Ortiz, A. (2012). Economic viability of selling locally

grown produce to local restaurants. Journal of Agriculture, Food Systems, and Community Development, 3(1), 181-198.

http://dx.doi.org/10.5304/jafscd.2012.031.014

Copyright (C) 2012 by New Leaf Associates, Inc.

\begin{abstract}
The purpose of this study was to conduct a qualitative comparative analysis of growers' costs for inputs related to production, processing, packaging, and distribution of local foods to independent restaurants. Growers have been motivated to sell locally due to the asymmetry in farm-retail price spreads. Yet selling locally direct to restaurants may imply new types of processes, costs, and investments. While local farm-to-retail markets may provide opportunities to reduce these price spreads and maximize benefits for growers, it

a* Corresponding author: Amit Sharma, Associate Professor of Hospitality Finance; School of Hospitality Management, The Pennsylvania State University; aus22@psu.edu

b Extension Specialist/Adjunct Professor; Apparel, Events, Hospitality Management, Iowa State University; cstrohbe@,iastate.edu

c Professor of Agricultural and Extension Education, The Pennsylvania State University; brr100@psu.edu

d Lecturer, University of Costa Rica; allmore@ucr.ac.cr
\end{abstract}

is unclear whether such efforts are economically viable for growers when all input costs are considered. Interviews with local food producers found that there were clearly higher costs for growers in most of the value chain for directly selling products to restaurants. Specifically, growers expressed a need for increased communication and interaction with restaurant buyers. Such interaction helped growers showcase their products to restaurants, yet required greater time inputs. However, premiums received by growers for these direct market sales were perceived to offset these costs. Local food is gaining popularity as an alternative economic strategy for developing local communities. For it to develop and be adopted progressively, however, clear costs and benefits need to be examined, evaluated, and communicated to producers and consumers.

\section{Keywords}

cost-benefit analysis, economic viability, growers, local foods, restaurants 


\section{Introduction}

Local food is viewed as an alternative economic strategy for developing local communities (Hinrichs, 2003). However, clear costs and benefits need to be examined, evaluated, and communicated to producers and consumers for this strategy to develop and be adopted progressively. Theories of economic sustainability such as eco-localism stress the importance of creating local or regional community economies that are self-reliant (Curtis, 2003). Emphasis has been placed on examining the economic possibilities that short-distance commerce and self-reliant local economies can offer. Research shows that while there may be significant environmental consequences of longer transportation of foods, actual transport costs are small. Therefore, shorter distances may not provide an economically competitive justification to choose local foods over the conventional system (Pirog, Van Pelt, Enshayan, \& Cook, 2001). In this study, Pirog et al. calculated the weighted average source distance for locally grown produce to reach institutional markets at 65 miles, compared to 1,494 miles for the same products to reach the same locations from conventional sources. Gas prices have increased significantly since that research was conducted, thereby increasing the likelihood that transport costs could be a consideration in choosing local foods. A more recent study investigating fuel efficiency and $\mathrm{CO}_{2}$ emissions of community supported agriculture (CSA) operations in Iowa found farmer delivery using the Toyota Prius resulted in 2.77 times lower fuel use and $\mathrm{CO}_{2}$ emissions than consumer pick-up using the U.S. average fuel economy for passenger vehicles (Pirog \& Rasmussen, 2008).

Markets for local foods have developed significantly. Local foods in restaurants have been identified as the "hottest trend" for 2009 and 2010 (National Restaurant Association [NRA], 2008; 2009a; 2009b). Reporting on "Finding Food in Farm Country" in over 30 states and tracking economic impacts of local food system developments, Ken Meter (2008) has found, for example, in an analysis of eight Iowa counties, that in 1998 three institutions were purchasing USD111,000 of local food, but in 200825 stores and institutions were purchasing USD1.8 million of local food.
(One success story is an independent restaurant called Rudy's Tacos, which in 2008 purchased 72 percent of its food from local sources.) Other than these regional-specific reports, there is limited research as to whether it would be economically viable for growers to sell directly to restaurants, and under what conditions these transactions could occur. Economic viability for growers is critical to ensure that local food sales directly to restaurants as a sustainable strategy.

This study was part of a broader effort that took a systems view to evaluate the economic viability of local foods for food service organizations, local growers, and consumers. This study assessed economic costs and benefits for growers in order to further inform the connection with the wider literature in theories of economic sustainability, eco-localism, and farm-to-fork system approach. Specifically, this study investigated the costs and benefits for growers when selling products directly to independent local restaurants. It also evaluated ways in which growers can maximize economic benefits and minimize costs when selling to local restaurants. This study also developed a baseline model to capture such observable impacts of marketing local foods to one sector of the food service industry, independently owned local restaurant establishments. There is limited understanding by producers of local restaurant value chain dynamics. Our study contributes to this literature gap. The findings of this study present an opportunity for producers to align their costsbenefits in a manner that would increase the value of their transactions with local restaurants.

\section{Literature Review}

\section{Local Food Movement}

Many communities have initiated an alternative food and agricultural system in response to trends in the current food system characterized by global and corporate control, too few companies retaining economic control and benefits, and a lack of environmental concern (Feenstra, 2002). Farmers' markets and community supported agriculture (CSA) organizations reflect the characteristics of a local food system. Consumer interest in using and buying local foods has increased over the past 
several years; this interest is reflected in the increased number of farmers' markets and CSAs in the U.S. Farmers' markets have experienced growth over the last two decades, with an increase of 33 percent in the number of farmers' markets between 1994 and 2009 (USDA, Agricultural Marketing Service, 2009). Data collected in 2007 by the USDA indicated that 12,549 farms in the United States reported marketing products through CSA arrangements (USDA, National Agricultural Library, 2007). The CSA concept is attributed to European and Japanese influences. CSAs were introduced in the U.S. in the mid-1980s. According to LocalHarvest estimates, the number of CSAs in the U.S. was 50 in 1990, with a current estimated number at about 2,000 (LocalHarvest, 2009).

Although there is widespread interest in local foods, there is no standard definition for local food. The term is fairly broad, with several different complementary and dynamic dimensions. Previous researchers have identified different definitions for what producers and consumers mean by local food, such as definitions framed around political boundaries, a specific distance from purchasing point to sale, and geographic place of production. Wilkins, Bowdish and Sobal (2000) examined several dimensions of the concepts "seasonal" and local food. Researchers surveyed 166 undergraduate students enrolled in an economics and nutrition class at a large university in New York. The authors concluded that meanings given for local foods involved distance, physical accessibility, and sometimes a dimension of specialty or uniqueness for products available in certain areas. Most meanings given to local food (65 percent of total responses) had to do with the place in which the food was produced.

Zepeda and Leviten-Reid (2004) conducted focus group sessions with food shoppers in Madison, Wisconsin, to investigate shopper beliefs and behaviors about local foods. The four focus groups consisted of two groups of regular organic food shoppers and two groups of shoppers who did not frequently purchase organic foods. A convenience sample was recruited from different sources to include specific ethnic and income groups. The sample included a Southeast Asian gardening community, an African American church group, members of a Slow Food group, and shoppers at a food co-op. The authors found that most participants defined local food relative to driving time. This criterion relates driving time to distance, with six to seven hours the most frequent answer to the question of the limit of time that would be spent to drive to a local food source. About half of the respondents in this study defined local food in these terms, with other responses such as product availability at farmers' markets or products from smaller farms also identified.

The Hartman Group (2008) reported the findings of a survey conducted in December 2007 about U.S. consumer understandings of the term "buy local." Results were based on a sample size of 796 and a contextual language analysis of hundreds of statements made by shoppers as well as online discussions about what buying local means. The report indicated that consumers defined local in terms of distance from their home: 50 percent defined local as within 100 miles, and 37 percent said within the same state. In view of these varied definitions of local food, this study defined local foods empirically by a preliminary review of the study sample's production and sales practices. This study defined local foods as that grown or produced for sale within a 50-mile radius of its source.

\section{Factors Influencing Food Choice}

A wide variety of factors can influence human food selection. Shepherd and Raats noted that "the range of factors potentially involved in human food choice is tremendously diverse and extensive" (2006, p. 2). They developed a food choice process model that incorporated and linked factors involved in making food selections. The model examined consumer individual food choices and identified three major components that overlapped and interacted when people constructed food choices: course of life (evolution of thoughts and feelings over time and transitions of time and place); influences (ideals, personal factors, resources, and social factors); and context (such as social institutions and policies). These food choice values change over time as events and experiences during the course of life shape food choice influences that may result in new or modified food choice values. Therefore, it is possible that in a 
long-term perspective, trends in preference for local foods could be transitory. However, in the near and short term these trends have strengthened. Restaurants are therefore finding ways to capitalize on these trends. Growers tend to benefit through such trends, and in the process may also better understand opportunities that exist to extend the benefits from a diverse set of marketing outlets.

\section{Motivations and Preferences for Buying Local Foods}

Many factors are considered in consumer food decision-making. Taste, convenience, cost, and health are among the most important influences on food purchases (Shepherd \& Raats, 2006). The identification of factors influencing the decision to buy local food is valuable knowledge that can be used by producers, restaurants, and food service institutions to define new marketing strategies. Research on consumer preferences of local food at farmers' markets and direct markets has determined some of the perceptions associated with these products and the motivations to buy local foods. In a study of consumer views on local food, Zepeda and Leviten-Reid (2004) also found that respondents had a positive attitude toward local foods because of its association with enhancing the economy and benefiting the environment.

Tregear and Ness (2005) conducted an analysis of consumer interest in locally produced foods in a region of England to determine what factors influenced their buying decisions. After reviewing the literature, the researchers hypothesized that three sets of factors were related to consumer interest in local foods: attitudes, situation, and demographics. The results of the study gave partial support to the hypothesis that interest in local foods was associated with relatively high levels of concern over food chain issues, as well as partial support to the idea that interest in local foods is associated with positive attitudes towards farmers. The study found that "contact with farming" was a strong discriminator of interest levels in local food. The demographic variable of "age" was the only significant discriminator, suggesting that interest in local foods is higher among older respondents. Carpio and Isengildina-Massa (2009) showed that premiums for local products were influenced by age, gender, and income as well by perceived product quality, a desire to support the local economy, patronage of farmers markets, and consumer ties to agriculture. While a wide variety of factors influence preference for local foods, an underlying factor is consumer concerns about the manner in which food moves along the local foods value chain. Sustainability of this value chain could be determined by its economic viability, yet it is unclear whether such value chains are economically viable.

\section{Business to Business Research in Local Foods}

There has been significant interest in local foods supply chains in the business-to-business (B2B) literature. For instance, Hardesty (2008) assessed the prospects for marketing locally grown produce (LGP) to colleges, universities, and teaching hospitals. The researchers examined the effects of transaction costs, institutional characteristics, and price proxy on the adoption of LGP-buying programs using survey data. The study found that colleges and teaching hospitals incur significant transaction costs and a price premium to have an LGP-buying program. As a consequence, the author suggested that growth of LGP programs required reducing transaction costs, to which grower collaboration and improved vertical coordination between growers and produce distributors was the key.

Strohbehn (2003) presented empirical evidence that food buyers for commercial and institutional food services in Iowa have strong interest in supporting local farmers, providing fresher and high quality foods, and lowering associated transportation costs. Data from the study also showed that operations wish to know the sources of foods purchased. In addition, the author suggested that commercial food buyers have more flexibility to adjust their menus according to seasonal harvest, while institutional food service operators have more concerns about product costs, labor time, and safety of food, and the food supply chain. Kirby (2006) investigated restaurants as a potential market channel for locally grown food in western North Carolina. The top challenges of purchasing locally reported in this study were coordinating purchase and delivery, and finding an adequate supply of locally grown food. Generating strong consumer 
demand for local food was also cited as critical to maintain restaurant demand for local food.

Keifer (2008) discussed locally grown food purchasing from retailer and supplier perspectives, and discussed the challenges within this supply chain. Both small regional food producers and larger national brands can benefit from local sourcing. Large food suppliers may embrace local production as a means of maintaining lower costs and competitive prices. Although the localsourcing trend offers the opportunity to reduce transportation, warehousing, and packaging costs by reducing food miles, it introduces new challenges for grocery retailers. Those challenges include wider variation in merchandise, reduced economies of scale, difficulties for supplier management, and more sophisticated pricing, ordering, and invoicing processes.

Kinsey and Buhr (2003) discuss how B2B relationships can reduce costs and increase efficiencies in the procurement, storage, and delivery of food to retail stores or distribution centers. The use of electronic commerce allows retailers to share information about consumer purchases and preferences with farmers, and to check food characteristics, sources, and movement from production to consumer. The authors state that this circle of information would allow high quality and consistent products to be consumed at lower prices.

In summary, the B2B literature shows that organizations could face economic challenges in sourcing local foods in a manner that could ensure sustainable demand for such products. The literature indicates that it would be worth explaining the sources of these transaction costs along the local food supply chain. The transaction costs are conceptually a measure of defining value within the value chain framework. In this study we adopt a value chain framework that helps identify the sources of these transaction costs.

\section{Benefits and Obstacles Perceived by \\ Food Service Institutions}

Gregoire and Strohbehn (2002) conducted a study with school food service operations to determine current purchasing practices, and identify benefits and obstacles when purchasing from local growers or producers. They found that respondents identified good public relations and support to the local economy as the strongest benefits of buying local foods. Other identified benefits were the possibility of purchasing smaller quantities, obtaining fresher and safer food, and knowing product sources. Among the obstacles identified by respondents were the lack of availability of products year around, the inconsistent ability of obtaining an adequate food supply for the operation's volume, and unreliable food quantity.

In another study, Strohbehn and Gregoire (2005) collected directors' perceived benefits and obstacles in purchasing local foods for college and university food service operations. Perceived benefits from buying local foods were support of local sources and regional economies, freshness of foods and foods of higher quality, good public relations, student awareness about food sources and production practices, availability of safer food, and the opportunity to purchase smaller quantities. Freshness and quality were identified as very important by this type of food service operation directors, as their mission was to provide safe and nutritious foods to students whose only access to meals may come from the dining service. Barriers identified in this study related to payment procedure conflicts, reliable suppliers, and product availability year round. Other studies have also identified benefits and obstacles of marketing local food products between farmers and different sectors of foodservices. Benepe, Smith, Auld, Starr, Lamm, and Wilken (2002) investigated the food purchasing patterns of restaurants and institutional food service in three Colorado regions. Researchers categorized the barriers identified by food buyers who directly purchased locally grown foods (less than one-third of the sample) as follows: lack of knowledge about local sources; inconvenient ordering procedures; and product concerns such as limited availability, variable cost, and increased service costs. Benefits associated included high customer satisfaction and the development of positive local business relations.

The Food Processing Center (2003) of the University of Nebraska conducted a mail and online survey of members of the Chefs Collaborative organization to identify attributes important to 
food service establishments, and the challenges and obstacles associated with purchasing locally grown food. Advantages that members gave to initiating or continuing the purchase of locally grown products were better product quality, the importance of developing good relations with producers, access to unique or specialty products, and satisfaction of consumer requests. Seventy-three percent of the responding chefs agreed or strongly agreed with the idea that purchasing locally grown food had a positive impact on the bottom line profits of the establishment. The identified obstacles were related to distribution and delivery, concerns about the reliability and consistency of supply, complicated ordering processes, and dealing with many suppliers. The study also found that chefs identified barriers related to pricing and competitiveness when other purveyors were competing.

Starr et al. (2003) investigated local food marketing and purchasing practices between farms and restaurants in Colorado. They determined that the important factors for local restaurants when purchasing food items from local producers were supporting other local businesses and acquiring products that minimized impact on the environment and that were grown and processed locally. Strohbehn and Gregoire (2003) conducted a case study with five independently owned restaurants and five non-commercial food service operations in Iowa to assess interest in increasing local food purchasing. Results showed considerable interest by all food buyers to support local farmers because of perceptions of fresher and higher quality products and because of lower transportations costs. Some of the non-commercial food service managers noted concerns about working with local suppliers, such as time of delivery, availability of items, consistent quality, and price of products. Inwood, Sharp, Moore, and Stinner (2009) examined the characteristics of chefs and restaurants that had adopted local foods, to identify important local food attributes and the role of the restaurants in promoting local foods. All restaurants expressed that the superior taste of local food was an important factor when making purchasing decisions. Among all restaurant respondents, a perceived barrier to widespread use of local foods was inadequate distribution infrastructure.

In summary, despite several obstacles to buying locally, restaurants (mostly independently owned) have noted the benefits of local foods which are associated with its taste, freshness, quality (in general), sustainability in the local community, and even profitability.

\section{Benefits and Obstacles Perceived by Producers}

Gregoire, Arendt, and Strohbehn (2005) investigated producer perceptions of marketing to local restaurants and other food service operations in Iowa. Perceived benefits of direct marketing and selling among the producers included supporting local farmers, providing fresher food for the customer, and less travel distance for food. Researchers found that almost 44 percent of respondents had never sold to local food service operations because they could not produce the quantity year-round with the specifications needed by buyers. Other reasons offered were lack of knowledge by producers and buyers about regulations, and that some purchasers were not open to buying from them. Kelley (2006) found it important for farmers to know what to produce, and then to market it effectively to professional chefs based on an understanding of chef needs. Similarly Penrose, Smith, and Vollborn (1999) found that farmers identified assistance for extending or improving markets, farm management, natural resource management, and increase of the grazing season for ruminant livestock, as important factors. Extension information on management of production input costs, niche markets and competitive channels of distribution, information on product handling practices prior to delivery, and marketing tools were also identified by farmers as important for direct selling to restaurants (Ellis, Strohbehn, \& Henroid, 2005; Strohbehn \& Gregoire, 2005; Sharma \& Strohbehn, 2006; Montri, Kelley, \& Sanchez, 2006; Sharma, Gregoire, \& Strohbehn, 2008). A number of studies have also found that establishing contact, and developing a lasting relationship with restaurants, marketing of produce, and identifying and implementing online collaborative marketing was important to farmers (Curtis, Cowee, Havercamp, Morris, \& Gatzke, 2008; Gao \& Bergefurd, 1998; 
Gregoire, Arendt, \& Strohbehn, 2005; Sustainable Agriculture Research and Education [SARE], 2008; Wright, 2005). Other studies have also recommended that growers and producers organize cooperative alliances to ensure that restaurants and other retail food services have sufficient quantities available for specific products when needed (Iowa State University Extension [ISUE], 2008).

Despite this growing research interest in local food value chains, the economic aspects of selling directly to local restaurants are still unclear. Limited peer-reviewed research has been conducted in this arena. Ken Meter's team at the Crossroads Resource Center in Minnesota has conducted numerous state and county-based reports on food production costs and sales within specific regions (see Local Food and Farm Studies at http://www.crcworks.org/?submit=fffc). Other food service focused studies have assessed consumer willingness and/or tracked actual purchase of promoted local foods (Sharma, Gregoire, \& Strohbehn, 2009; Strohbehn \& Ortiz, 2011). A more thorough comparative analysis of costs of production, processing, packaging, and distribution is needed to justify use of local food systems. Growers are motivated to sell locally due to the asymmetry in farm-retail price spreads: costs to farmers may change by only 16 percent, yet the price to consumers (through wholesale market channels) can go up by as much as 52 percent (Dunham, 1994). Selling locally may imply new types of processes, costs, and investments, simply because growers are approaching a different market to sell their produce (Telfer \& Wall, 1996). While local farm-to-retail markets provide opportunities to reduce these price spreads and maximize benefits for growers, it is unclear whether such efforts would be economically viable for growers. Recent literature has also evaluated value chain aspects of local food selling to different types of consumers. For instance, recently Jablonski, PerezBurgos, and Gomez (2011) evaluated the scale of marketing and distribution components of the farm value chain in selling local foods to a broad cross-section of consumers. Bloom and Hinrichs (2011) investigated approaches that would be optimal for hybrid value chains, when conventionally oriented businesses incorporate local value chains. They suggest that focusing on noneconomic and informal mechanisms such as social relationships could be beneficial. Schmidt, Kolodinsky, DeSisto, and Conte (2011) investigated the marketing and distribution strategy of a Vermont-based CSA, and found several implications concerning value chain components. In particular, the study found that while the CSA had improved distribution and access of local foods to consumers, overhead costs and upfront consumer costs were a hindrance to its sustainability.

The purpose of this study was to assess qualitatively the economic costs and benefits for growers who sell their products directly to restaurants. Specifically, the objective of this study was to identify economic implications for local growers/ producers who wished to establish sustainable partnerships with local restaurants. The two research questions that guided the study were:

1. What are the costs and benefits for growers to sell products directly to independently owned restaurants?

2. How can growers maximize the economic benefits and minimize costs when selling to local restaurants?

\section{Applied Research Methods}

This research used a qualitative approach to investigate the questions. As has been briefly discussed, there is, at best, scant evidence of the total costs (direct and indirect) and benefits for local growers selling directly to local restaurants. Therefore, a qualitative research design allowed us the flexibility to better understand various dynamics of costs-benefits associated with direct sales to local restaurants. Four criteria outlined by Creswell (2003) were used to carry out this qualitative study: (1) a strong literature base for the study, (2) use of questions to explore the meanings of the situation/ experience being studied, (3) data collection using interviews, and (4) analysis of data by grouping the responses (termed horizontalization) to form clusters of meanings.

As shown in the introduction to this paper, recent literature on costs and benefits associated with local food value chain to restaurants was discussed. Based on literature review and the 


\section{Figure 1. Proposed Value Chain Framework}

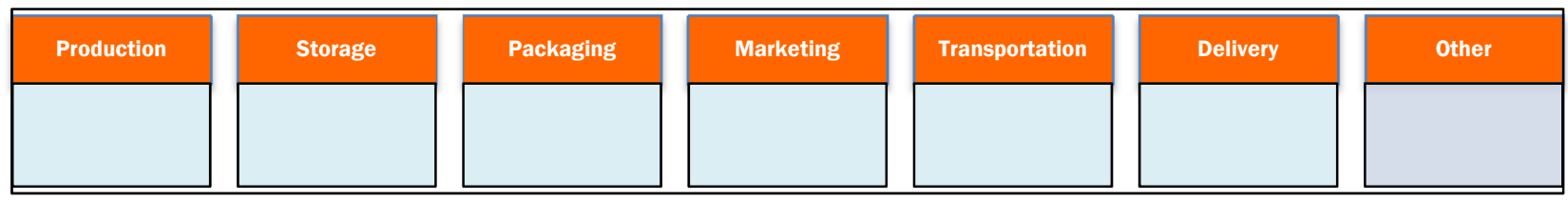

authors' own experiences in the field, questions were developed to explore the meanings of costs and benefits along the value chain in directly selling locally grown produce to restaurants. Interviews, the third criteria proposed by Creswell, allowed the integration of the first two criteria by securing enough time for respondents to explore the meanings of costs and benefits. Finally, the analysis of data helped the authors to identify themes that were compiled to form clusters of meanings along each component of the value chain (see figure 1). These clusters of meanings were described and supported by verbatim comments.

The purpose was to identify incremental costs and input investments (both tangible and intangible, such as time) required by growers and producers who sell local foods to independently owned local restaurants. This study was conducted through a Midwestern university and approved by its institutional review board. Data for the study was gathered through face-to-face interviews with 10 local growers/producers who sold food to local restaurants. The criterion for selecting producers was that they currently sold produce directly to local restaurateurs. The intention of the producer survey was to understand costs and inputs involved (operating and capital costs, and labor time) in selling locally, which was achieved by interviewing producers already selling to local businesses and having understanding of these inputs. Producers were identified through a local grower directory. First contact was established via phone with a request for participation, and to develop a definition for local foods based on producers' current local selling activities. A value chain framework was adopted to assess the direct and indirect costs required by growers and producers who sold local foods directly to restaurants. The value chain components, previously used as a framework for other research, included the following: production, storage, packaging, marketing, transportation, delivery, and other (Sharma, Gregoire, \& Strohbehn, 2009). The last category, 'other,' included activities such as billing and administrative aspects. See figure 1.

Face-to-face interviews were conducted with10 local growers/producers identified who were selling fruits, vegetables, dairy, chicken, pork, or beef to at least one local restaurant. This judgment sample (Marshall, 1996) of growers and producers was selected from a list of farmers obtained from a regional subsidiary of a national philanthropic organization that supports local food systems. As Marshall (1996) points out, the size of the sample for a qualitative study is primarily driven by the phenomenon of interest in the research question. Therefore a small sample size in a qualitative study is justified, because the objective is to understand the phenomenon of interest and not to generalize the findings. In this research, the phenomenon of interest was local growers and producers directly selling to restaurants. We selected a sample from the local grower and producer database in order to recruit respondents at different levels of their involvement, commitment, and interest in selling to restaurants. This was accomplished during the initial phone discussions, and through subsequent discussion among the researchers who assessing the producers' interest levels — whether they were interested in selling to local restaurants, were new to this marketing option, or had prior experience. Such sampling allowed us to ensure that we would be able to investigate our phenomenon of interest in a comprehensive manner. Local food was defined as product sold by growers and producers within a 50-mile radius, based on phone intake data. Interviews were prescheduled, and the growers were given a copy of the instrument before the interview. The instrument was based on prior studies conducted in the context of direct sales by local growers (Ellis, Strohbehn, \& Henroid, 2005; Strohbehn \& Gregoire, 2005). The 
Figure 2. Associated Costs of the Resultant Value Chain Framework

\begin{tabular}{|l|}
\hline \multicolumn{1}{|c|}{ Production } \\
\hline - For the most \\
part, no \\
differences in \\
costs, except \\
the cost of \\
hoop houses; \\
others \\
unclear \\
\\
\end{tabular}
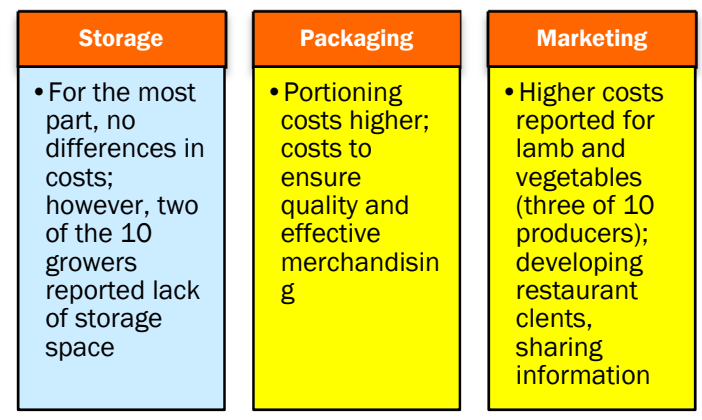
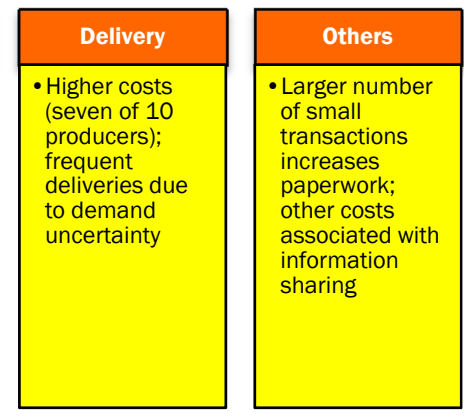

instrument had three sections. Section I included questions about grower information, ownership, farm characteristics, types of products grown, number of employees, and the usual methods of advertising and marketing. Section II consisted of a series of questions about grower experience dealing with restaurants. These questions asked the growers about their experience dealing with local restaurants, challenges and benefits, types of products they sold, and whether they would be interested in continuing to increase sales to restaurants. Section III asked the growers to provide any specific cost-related information when comparing direct sales to restaurants with other sales outlets. The researchers incorporated the flexibility to allow respondents to provide additional comments that were related to these questions. The discussions were semi-structured and conducted by at least two research team members. One researcher recorded the responses during the interview. A debriefing session followed in which both members of the research team verified responses. Frequency of responses and other descriptive and nonparametric statistics were used to analyze the data. Responses were also grouped (horizontalization) to form clusters of meanings. Researchers also collected cost information, perceptions of benefits, and descriptive documentation of current practices.

\section{Results}

Grower responses were categorized into three distinct areas: grower information, issues concerning sales to local restaurants, and value chain component information about costs and benefits. Results pertaining to costs and benefits that growers identified in the respective value chain activities are presented below. These results are also supported by statements pertaining to the appropriate costs and benefits from interviews concerning sales to local restaurants.

\section{Costs and Benefits for Growers}

Each value chain activity was investigated for its reported costs and benefits.

Production costs: As shown in figure 2, most of the producers $(n=8)$ noted that there were no differences in production cost between food for local restaurants and for conventional markets. However, two of the growers interviewed did report that there could be differences in production costs. One of these growers was not monitoring such costs, and therefore was unable to identify cost differences clearly. The other producer noted that selling to restaurants would require investing in a hoop house, which could require significant investment, of up to USD6,000. The hoop house would ensure that off-season produce could be made available to restaurants, or at a minimum extend the growing season and availability of produce to restaurants.

Storage costs: As for production costs, most growers noted that storage activity also did not result in higher costs when marketing and selling directly to local restaurants over costs when selling to conventional markets. However, two of the 10 growers suggested that their current storage capacity was limited. Thus, an implication may be that additional storage would cost more, thereby increasing transaction costs for local independent restaurant markets.

Packaging costs: Two of the 10 growers reported that packaging costs for tomatoes, aspara- 
gus, and corn were higher, due to portioning specifications of their buyer restaurants, than when products were sold directly to consumers at conventional markets. Another three growers reported that the cost of ensuring quality, whether through processing or packaging, would be higher when selling to restaurants. Growers and producers also reported that packing and merchandising skills appeared to be lacking among other growers interested in direct sales to local restaurants. This lack of skills could also increase inefficiencies, thereby increasing costs to growers and producers.

Marketing costs: Lamb producers and vegetable growers reported higher marketing costs for establishing initial contact and later relationship building with restaurants. Three other growers reported that marketing costs of communicating essential product, price, and other sales and merchandising information to restaurants would be higher than if they were to sell to conventional market outlets such as farmers' markets, roadside stands, food distributors, grocery stores, and middlemen. Furthermore, aligning market needs to ensure adequate supply of their products to restaurants also created uncertainties, particularly because of noncommittal ordering from restaurants. On the other hand, seven respondents also reported several marketing benefits of selling directly to local restaurants. For instance, they felt that local restaurants could provide effective advertising for their products. This was found particularly attractive given the potential price premium for their products associated with consumers visiting such restaurants. Furthermore, eight felt that restaurants provided them with an alternative market, thereby allowing them to diversify their marketing strategy.

Transportation and delivery costs: Most important, all 10 growers agreed that transportation and delivery costs were higher selling directly to restaurants rather than selling through wholesalers, CSAs, and other marketing outlets such as farmers' markets. Transportation costs were reported as higher due to several factors. The biggest contributor to transportation costs, as identified by seven of the 10 producers, seemed to be the uncertainty attached to both the restaurant demand pertaining to specific products, as well as the quantities required of these products. This would imply that growers and producers would have to make frequent trips to the restaurants, sometimes more than once or twice a week. While this helped them in establishing relationships, the unit costs were sometimes prohibitive. For instance, when delivering asparagus rather than corn, usually corn would be ordered in higher quantities; therefore the growers could justify this based on unit costs. Six growers also reported that they did not effectively communicate product and pricing information to restaurants. This created uncertainty of product availability from the producer/grower end for the restaurant, further impacting the restaurant's ability to plan menu items using local ingredients. Restaurants lack of forecasting and planning further fueled the uncertainty of product demand for producers and growers.

Other: Additional factors that had potentially higher costs included billing and the amount of paper work involved in the number of transactions, due to restaurants requiring smaller amounts of product in each transaction, compared with amounts sold with wholesaler transactions. However, producers were uncertain as to how much this difference in cost would be. Most important, nine of the 10 producers and growers felt that they must differentiate their products in order to maximize their returns from the restaurant market. Several obstacles were noted in this regard, such as a general lack of training to create product differentiation, and of course the additional costs involved in doing so. Communication between growers/producers and restaurants was also cited as an important obstacle that was likely increasing transaction costs. On the other hand, several growers and producers noted that they could charge a price premium to local restaurants. Nine of the 10 growers agreed that restaurants would be willing to or did pay a price premium for their products. Furthermore, sales to restaurants could improve growers' and producers' financial liquidity and improve cash flows.

There were other factors identified by growers and producers as potentially influencing their costs and benefits. Some quotes from respondents are listed by category in table 1 . 
Table 1. Costs and Benefits of Local Food Value Chain to Restaurants: Respondent Quotes

\begin{tabular}{|c|c|c|}
\hline Value Chain & Costs & Benefits \\
\hline Production & $\begin{array}{l}\text { “Product costs will differ but we don't track those." } \\
\text { “Hoop house[s] [are] necessary for most growing. } \\
\text { [This would let us] better control...weather } \\
\text { [effects]...[improve] yields, [and also allow us to] } \\
\text { change crops easily." }\end{array}$ & \\
\hline Storage & $\begin{array}{l}\text { "[There is also] not much storage." } \\
\text { "Potentially [there could be a shortage of] storage } \\
\text { space, coolers, [and higher] labor production } \\
\text { costs." }\end{array}$ & \\
\hline Packaging & $\begin{array}{l}\text { "[Restaurants] need product portion controlled." } \\
\text { "Cost of processing-cuts, [and] cost of packaging." } \\
\text { "Cost of processing, quality of workmanship, and } \\
\text { package." }\end{array}$ & \\
\hline Marketing & $\begin{array}{l}\text { "Restaurants and growers [could] come together } \\
\text { and talk, at least [from time to time]...[and] } \\
\text { share information [related to] products, prices, } \\
\text { timing [of deliveries].” } \\
\text { "We seem to be afraid of rejection." } \\
\text { "Demand/supply [mis] match [exists]. [For } \\
\text { instance], when they need it we don't have it, } \\
\text { [and] when we have it, they don't need it." }\end{array}$ & $\begin{array}{l}\text { "Advertising through the restaurant is good. Upper } \\
\text { market gets to know us." } \\
\text { “[Restaurants can be an] alternative market [so that } \\
\text { we are] not totally dependent on farmers' market." } \\
\text { "Can't prove that [restaurant sales] does marketing. } \\
\text { [Though] can be steady customers if we monitor } \\
\text { quality, develop relationships..." } \\
\text { "Celebrity chefs...are our spokesmen [for] marketing } \\
\text { in general." }\end{array}$ \\
\hline Transportation & $\begin{array}{l}\text { "[We experience] hard time of on delivery...[that] } \\
\text { may be not the same day." } \\
\text { "Transport, delivery, coordination, and } \\
\text { communication is key, [as is] relationship... } \\
\text { because product knowledge is critical for chefs." }\end{array}$ & \\
\hline Delivery & $\begin{array}{l}\text { “[Restaurants require] services [such as] delivery } \\
\text { [of products]- order processing." See additional } \\
\text { comments in Transportation. } \\
\text { "Delivery costs, [because it] takes time for initial } \\
\text { costs [of establishing restaurant clients] and } \\
\text { delivery time. [For instance,] asparagus is worth } \\
\text { the time but not corn as much, unless they take } \\
\text { quantities." }\end{array}$ & \\
\hline Others & $\begin{array}{l}\text { "[Need to] differentiate the products by name." } \\
\text { "Restaurant demand is down in summer when } \\
\text { we have more." } \\
\text { "Restaurants don't even know what is available, } \\
\text { so farmers must provide this information } \\
\text { [related to] products, quantities, and prices. } \\
\text { [While restaurants] could be a good option... } \\
\text { [we need]... some help to provide reliable } \\
\text { communication. [For instance] provide internet } \\
\text { capabilities for farmers; education capability } \\
\text { and network[ing]." }\end{array}$ & $\begin{array}{l}\text { “[Restaurant] could be premium price market } \\
\text { [could] take time [to reach that stage]; [restaurants } \\
\text { also require] higher volume." } \\
\text { "We charge higher to restaurants (10-20 percent) } \\
\text { because consumers can pay more.” } \\
\text { “[I] found it more satisfying to have relationship with } \\
\text { buyers... [especially when] something [was] } \\
\text { requested. [Also it was] more interesting to grow } \\
\text { summer baby squash and deliver to consumers." } \\
\text { "[Selling to customers could] solve some cash flow } \\
\text { problems." } \\
\text { "Could get extra revenue by differentiating price by } \\
\text { market, but haven't done so, supply in small } \\
\text { community." }\end{array}$ \\
\hline
\end{tabular}


1. As noted earlier, restaurants were usually unable to commit in advance for orders. This created uncertainty for the producers, and therefore placed a constraint on planning their production. For instance, some growers commented that advance orders would allow the producers to invest in hoop houses, thereby ensuring that off-season products such as tomatoes and other vegetables would be available.

2. There was a perceived lack of commitment from farmers to sell directly to restaurants. Some of the farmers (producers) interviewed argued, however, that this commitment was also a function of restaurant commitment to purchase from local growers and producers.

3. On the other hand, growers felt that some restaurants (along with their chefs) were considerably better than other types of retail food services, such as schools, in offering flexible purchasing policies, allowing growers to increase sales to such restaurants.

Surprisingly, the growers who felt this way were also the most active in directly selling locally to local independently owned restaurants.

4. Other growers observed that restaurant chefs needed to be better informed and trained to work with different types of products, allowing growers to market a variety of products.

5. A need was also identified for growers to engage in interactions and establish relationships with restaurant buyers, in order to sell their products.

\section{Discussion}

Fewer growers and producers noted higher production and storage costs for selling to local restaurants. There were clearly higher costs to growers for packaging, transportation, and delivery when selling to local restaurants than when selling directly to consumers. Restaurants are used to standard packaging of products; organizational recipes are often written to reflect these units. Thus, in some cases, producers are expected to comply with the current status. In other situations, restaurant chefs and buyers, particularly those that are single-unit and independently owned, are more flexible and willing to showcase local products as part of menu specials or new house recipes.

Restaurants that are part of a chain, or institutional food services, are often bound by organizational procurement policies to purchase foods from an approved vendor; thus, there is not the flexibility to procure locally. CSAs often require shareholders to pick up product, thus omitting producer inputs related to transportation and delivery as this cost is borne by the consumer. Farmers' market sales require less expensive packaging (clear plastic bags versus standard food package fiberboard containers, for example) and transportation is limited to one location. The flip side of restaurant purchasing flexibility is lack of commitment to purchasing from local producers. This impacted grower ability to plan effectively. Inability to plan production resulted in inefficient use of production capacity or higher inventories that have to be sold at relatively lower prices or accounted for as wastage, resulting in increased production and inventory storage costs. Thus, the average price that farmers could get from selling locally was lowered. In addition, producers were not clearly committed to the retail food service market, which may have impacted some farm improvement decisions, such as investing in a hoop house to extend the growing season and broaden variety of produce available year round or developing marketing and communication systems specific for a sector of the market. Lack of investments in production technology could also impact potential costs or benefits to the growers. These impacts could influence independent restaurants' decisions to buy from local farmers. There were other reasons for the lack of commitment by growers to further investigate sales to restaurants. For instance, one grower felt that direct marketing was too complicated and they were satisfied simply selling directly to the wholesaler, while others enjoyed the farmers' market and CSA connection to customers. In another instance, the grower did not feel that restaurants were appreciative of local produce, and thus were reluctant to pay a premium. Other studies have found retail food services, most notably institutional sectors such as hospitals, are cautious about purchasing from local producers due to uncertainty about regulations 
('Are we allowed to?'), taking extra time to search the market and communicate food specifications to the producer, and considering food safety (Gregoire \& Strohbehn, 2002; Starr et al., 2003; Strohbehn \& Gregoire, 2003). Most growers also identified benefits of selling to local restaurants, such as price premiums. Further exploration of quantification of the premium and the profit when all input costs are considered is needed to aid producers and restaurants in the decision- making process (Sharma, Gregoire, \& Strohbehn, 2009; Strohbehn \& Ortiz, 2011). In this study, restaurants were also considered an effective ally in advertising and marketing products to a wider market of consumers, potentially those able to pay a price premium for such products. However, growers expressed a need for increased communications and interactions with restaurants. Such interactions would help growers showcase their products to restaurants. Growers also suggested that a roundtable discussion amongst restaurants and growers would help establish contacts and develop professional relationships.

There are a number of areas where interventions (through community-based regional food systems and government agencies such as the USDA and Cooperative Extension) can play a role in supporting direct marketing of local foods to local food service establishments, such as local independently owned restaurants. This is one sector of the retail food industry with the most flexibility in terms of procurement decisions, unlike federal child nutrition programs or other institutional food services that may serve at-risk clients. Yet all sectors of the food service industry have expressed interest in local foods; for example, the Child Reauthorization Act of 2010 (also known as the Healthy Hunger Free Kids Act) formalized Farm to School programs. Inputs related to ensuring food safety are increasing in importance; some producers may need to comply with new Food Safety Modernization Act standards (fresh produce standards are currently in development), or find that restaurant organizational procurement policies are driving new producer requirements, which may increase their costs. Costs related to GAPs (good agricultural practices) certification or farmer documentation of on-farm food safety practices may be incurred. Independent restaurants have greater flexibility in the procurement process; yet all sectors of the food service industry have expressed interest in local foods. Guidance for both restaurants and producers (buyers and sellers) is needed to address regulation questions, production standards, and third-party certification requirements.

The results of this study suggest in a descriptive manner that support programs related to transportation and delivery activities would likely be the most popular ones to impact producer costs. Other programs that may impact costs involve packaging, marketing, and contracts (Ellis \& Strohbehn, 2006). Tools to aid producers in the decision-making process are available (see the Production Calculator Tool at http://www.iastate localfoods.org). Outreach education is readily available from most land grant universities through Cooperative Extension, such as the MarketReady Training Program offered by the Food Systems Innovation Center at the University of Kentucky or the University of Nebraska-Lincoln Food Processing Center. Local foods work is also emerging as an interdisciplinary area of inquiry with centers such as the Sustainable Agriculture and Food Systems Center at the Michigan State University and the Leopold Center for Sustainable Agriculture at Iowa State University which coordinate research and projects and disseminate information. Among the factors noted by growers that influenced costs and benefits, it would appear that several types of intervention strategies and programs could help initiate and develop relationships with restaurants and other sectors of the food service establishments in their communities. For instance, what approaches could be used to address sustainability of food production and consumption locally? What appropriate delivery mechanisms are needed, especially in the area of costs and benefits (value chain framework) to approach these unique audiences? As suggested by Thomson, Radhakrishna, Maretzki, and Inciong (2006), the broader context of food system programming at the local level and impacts on regional economies should be further explored.

The findings of this study also offer a myriad of potential opportunities and issues to address 
local food systems. These are grouped under educational programming, further research, and policy.

\section{For Educational Programming:}

1. Educational programs relative to food systems at the local level should target a new set of audiences such as small growers, restaurant owners, institutional or non-commercial food services, farmers' market groups, etc. Targeting new audiences will broaden focus and outreach at the community level.

2. Workshops emphasizing cost-benefit analysis models for both producers and independent restaurants, as well as noncommercial food services in the local food system, could be offered and evaluated periodically.

3. The need exists for collaborative efforts with local and state agencies, food service establishments including restaurants, and other stakeholders interested in advancing local/regional food systems.

4. Local food system efforts could be integrated with regional economic development and rural entrepreneurship activities, education center curricula, and community health and wellness programs; thus stakeholders concerned about economic, environmental, and social justice could engage in partnerships.

5. The findings of this study have potential for developing educational materials relative to value chain framework and cost-benefit analysis. Restaurant buyers and other food service managers would benefit from knowing the return on investment -in featuring local food items on menus. While limited research has been conducted (Sharma et al, 2009; Strohbehn \& Ortiz, 2011), more is needed. Program/information materials should address needs of growers and local service establishments relative to creating awareness and understanding, and aiding in decision-making, which is of vital importance in this era of accountability.

6. Training programs on how to target restaurants and other sectors of retail food services for marketing and selling products should be offered. Producers and growers will find this information useful in marketing and selling their products to restaurants effectively. For instance, chef and manager commitments would be a good beginning, but this information should emphasize to the producer that for a sustainable relationship the restaurant must make local food usage profitable by appropriately planning and marketing menu items. Producers and restaurants should also become conscious of the usual information asymmetry that exists between the two parties. If somehow information sharing can be streamlined and made more available from each to the other, then it is likely that growers and local restaurants may enjoy a more sustainable and long-term partnership.

\section{For Further Research:}

The findings of this study based on qualitative research methodology have provided valuable information in understanding grower and producer perceptions of the costs and benefits of direct sales to restaurants, and of the value chain framework. Similar studies should be conducted in other states to identify similarities and differences. In addition, future researchers in this area should consider the use of mixed methods approaches (qualitative and quantitative data collection) to further understand the complex nature of costs and benefits and their relationships to the value chain framework.

For Policy:

These findings should be shared with all stakeholders and decision makers involved in food procurement, particularly community planners and food assistance programs. Local food systems have implications for environmental stewardship, land use, transportation networks, procurement, biosecurity, community development, social justice, and immigrant rights, among other broader community concerns. Such sharing will help make informed decisions relative to local food system policy formation at the local, state, regional, and national levels. Better policy decisions will strengthen direct marketing and selling efforts by growers and producers. This would enhance the marketability of locally grown and produced foods, and potentially improve economic margins of the sellers. Consumers would also have more frequent 
choice of a variety of locally grown and produced foods. Research shows that older consumers prefer local foods. Current demographics suggest an increasing number of consumers in this age group. Improved access (and supply) of local foods, particularly in restaurants, would be preferred by this consumer group.

\section{Conclusions}

There were clearly higher costs for growers in several components of the value chain process for directly selling produce to restaurants. However, most growers also identified benefits, such as price premiums. Further, growers expressed a need for increased communication and interaction between growers and restaurants, in order to help growers showcase their products to restaurants and restaurant patrons, and further professional relationships.

The research design used in this study with a value chain framework has potential application for the assessment of operating costs and benefits of restaurants and other retail food services. Information for evaluating costs and benefits were found to be extremely fragmented, and the process of doing these evaluations were highly heterogeneous. Qualitative research by nature is richly descriptive, and allows for unique characteristics of local growers and local restaurants to be fully explored. A small sample size and case study approach here provided meaningful findings, more so than attempting large-sample data collection using a "shotgun" approach. Empirical research among producer groups and sectors of retail food services have yielded useful information relative to attitudes and perceived benefits of local food connections (Gregoire \& Strohbehn, 2002; Gregoire, Arendt, \& Strohbehn, 2005; Strohbehn \& Gregoire, 2005). Yet research questions which address "why" and "how" questions can be explored with qualitative approaches, as local food systems engage multiple stakeholders and provide all members of the community with a voice in the process. Even in small sample sizes, investigations can be more focused than attempting to generalize the study findings. In all, research in operational analysis and decision-making processes will find the results of this study useful and relevant.
This study's contributions to the practice of community-based agricultural and food system developments are numerous. The study results offer valuable insights in understanding the processes involved in distribution of produce from farm to the restaurants. Community-based agricultural practitioners and Extension educators can provide a link for better understanding the processes involved in distribution of produce from farm to restaurant. Perhaps a networking group of local food producers and restaurants could be formed to make informed decisions about the processes involved. Such engagement will provide opportunities for building trust, open and honest communicating, determining needs, and reducing uncertainties.

Conversation between local food producers and restaurants could help create dynamic menus that accommodate seasonally grown foods. Such conversations may help local food producers produce fruits and vegetables that have a longer shelf life. In other words, producers can plan ahead of time based on the needs of restaurants. Finally, these findings have shed light on the viability of selling directly from farmers to restaurants. A need exists for a conversation between producer groups and restaurants regarding the costs associated with direct selling. A crucial point here is communication via conversation for mutual benefit.

As stated earlier, the purpose of this research was to conduct a qualitative assessment of costsbenefits associated with selling locally grown and produced foods directly to independent restaurants. This study explored the factors that are critical for local growers and producers to consider when attempting to sell directly to independently owned restaurants. We identify factors that may in the future be quantified for wider generalizability.

\section{References}

Benepe, C., Smith, K., Auld, G., Starr, A., Lamm, D., \& Wilken, K. (2002). Cultivating local foodlinks. Journal of Applied Hospitality Management, 5(1), 52-57. Retrieved from Hospitality \& Tourism Index. 
Bloom, J. D., \& Hinrichs, C. C. (2011). Informal and formal mechanisms of coordination in hybrid food value chains. Journal of Agriculture, Food Systems, and Community Development, 1(4), 143-156. http://dx.doi.org/10.5304/jafscd.2011.014.016

Carpio, C. E., \& Isengildina-Massa, O. (2009). Consumer willingness to pay for locally grown products: The case of South Carolina. Agribusiness, 25(3), 412-426. http://dx.doi.org/10.1002/agr.20210

Creswell, J. W. (2003). Research design: Qualitative, quantitative, and mixed methods approaches. (2nd ed.) Thousand Oaks, California: Sage.

Curtis, F. (2003). Eco-localism and sustainability. Ecological Economics, 46(1), 83-102. http://dx.doi.org/10.1016/S0921-8009(03)00102-2

Curtis, K. R., Cowee, M., Havercamp, M. J., Morris, R. L., \& Gatzke, H. M. (2008). Marketing local foods to gourmet restaurants: A multi-method assessment. Journal of Extension, 46(6), Article 6RIB2. Retrieved from http://www.joe.org/joe/2008december/rb2.php

Dunham, D. (1994). Food costs - From farm to retail in 1993 (Agriculture Information Bulletin, No. 698). Washington, D.C.: United States Department of Agriculture.

Ellis, J. D. \& Strohbehn, C. H. (2006). Local food connections: Contracting with foodservices (PM 1853d). Ames, Iowa: Iowa State University Extension. Retrieved from http://www.extension.iastate.edu/ Publications/PM1853D.pdf

Ellis, J. D., Strohbehn, C. H., \& Henroid, D. H. (2005). Assessing on-farm food handling practices of Iowagrown produce and eggs in regard to food safety. Journal of Food Protection and Trends, 25(10), 758-761.

Feenstra, G. (2002). Creating space for sustainable food systems: Lessons from the field. Agriculture and Human Values, 19(2), 99-106. http://dx.doi.org/10.1023/A:1016095421310

Food Processing Center. (2003). Approaching foodservice establishments with locally grown products. Lincoln, Nebraska: Institute of Agriculture and Natural Resources, University of Nebraska.

Gao, G., \& Bergefurd, B. (1998). Culinary herbs as alternative cash crops for small scale farmers in southern Ohio. Journal of Extension, 36(6), Article 6RIB1. Retrieved from http://www.joe.org/joe/ 1998december/rb1.html
Gregoire, M. B., \& Strohbehn, C. H. (2002). Benefits and obstacles to purchasing food from local growers and producers. Journal of Child Nutrition \& Management, 26(1), 1-7. Retrieved from http://docs.schoolnutrition.org/newsroom/jcnm/ 02spring/gregoire/

Gregoire, M. B., Arendt, S., \& Strohbehn, C. H. (2005). Iowa producers' perceived benefits and obstacles in marketing to local restaurants and institutional foodservice operations. Journal of Extension, 43(1), 1-10. Retrieved from http://www.joe.org/joe/2005february/rb1.php

The Hartman Group. (2008). Pulse report: Consumer understanding of buying local. Retrieved from http://www.hartman-group.com/hartbeat/2008$\underline{02-27}$

Hinrichs, C. C. (2003). The practice and politics of food system localization. Journal of Rural Studies, 19(1), 33-45. http://dx.doi.org/10.1016/S07430167(02)00040-2

Inwood, S. M., Sharp, J. S., Moore, R. H., \& Stinner, D. H. (2009). Restaurants, chefs and local foods: Insights drawn from application of a diffusion of innovation framework. Agriculture and Human Values, 26(3), 177-191. http://dx.doi.org/10.1007/s10460-008-9165-6

Iowa State University Extension [ISUE]. (2008). Local food connections from farms to restaurants. Ames, Iowa: Cooperative Extension Service, Iowa State University. Retrieved from http://www.extension. iastate.edu/Publications/PM1853B.pdf

Jablonski, B. B. R., Perez-Burgos, J., \& Gómez, M. I. (2011). Food value chain development in central New York: CNY Bounty. Journal of Agriculture, Food Systems, and Community Development, 1(4), 129-142. http://dx.doi.org/10.5304/jafscd.2011.014.015

Kelley, K. M. (2006). Marketing to professional chefs. University Park, Pennsylvania: The Pennsylvania State University, College of Agricultural Sciences, Cooperative Extension. Retrieved from http://extension.psu.edu/farm-business/ farmentrepreneurs/marketing/marketing-strategiesfor-specific-audiences/ValueAddedMarketing. $\mathrm{pdf} / \mathrm{view}$

Keifer S. (2008). Food supply chains: Is shorter better? Retrieved 24 April 2012 from the All About B2B website: http://www.gxsblogs.com/keifers/2008/ 08/food-supply-chains-is-shorter-better.html 
Kinsey J. D., \& Buhr, B. L. (2003). E-Commerce: A new business model for the food supply/demand chain. Working Paper 03-01, the Food Industry Center, University of Minnesota. http://ageconsearch.umn.edu/handle/14320

Kirby L. D. (2006). Restaurants as a potential market channel for locally-grown food in Western North Carolina. Retrieved from http://www.asapconnections.org/special/research $\angle$ Individual $\% 20$ reports /Restaurants $\% 20 a s \% 20 a \% 2$ 0Potential $\% 20$ Market $\% 20$ Channel.pdf

LocalHarvest. (2009). Community Supported Agriculture. http://www.localharvest.org/csa/

Marshall, M. N. (1996). Sampling for qualitative research. Family Practice, 13(6), 522-526. http://dx.doi.org/10.1093/fampra/13.6.522

Meter, K. (2008). Local food and farm economy studies: Iowa. Retrieved from the Crossroads Resource Center website: http://www.crcworks.org/?submit=fffc

Montri, D. N., Kelley, K. M., \& Sanchez, E. S. (2006). Direct marketing edamame (glycine max [L.] merrill) to professional chefs. Journal of Extension, 44(1), Article 1RIB4. Retrieved from http://www.joe.org/joe/2006february/rb4.shtml

National Restaurant Association [NRA]. (2008). Chef survey: What's hot in 2009. Retrieved from http://restaurant.org/pdfs/research/2009chef survey.pdf

National Restaurant Association [NRA]. (2009a). Chef survey: What's hot in 2010. Retrieved from http://www.restaurant.org/pdfs/research/ whats hot 2010.pdf

National Restaurant Association [NRA]. (2009b). The dish on the local food movement: Trends, facts and statistics. Retrieved from http://www.markethouse chicago.com/uploads/file/Trend Sheet.pdf

Penrose, C. D., Smith, P. L., \& Vollborn, E. M. (1999). Production, processing, and marketing opportunities for Athens County, Ohio farmers: Assessing needs and creating solutions. Journal of Extension, 37(6). Retrieved from http://www.joe.org/joe/1999december/rb2.html

Pirog, R. (2003). Ecolabel value assessment: Consumer and food business perceptions of local foods. Ames, Iowa: Iowa State University, Leopold Center for Sustainable Agriculture.
Pirog, R., \& Rasmussen, R. (2008). Food, fuel and future: Consumer perceptions of local food, food safety and climate change in the context of rising prices. Ames, Iowa: Iowa State University, Leopold Center for Sustainable Agriculture.

Pirog, R., Van Pelt, T., Enshayan, K., \& Cook, E. (2001). Food, fuel, and freeways: An Iowa perspective on how far food travels, fuel usage, and greenhouse gas emissions. Ames, Iowa: Iowa State University, Leopold Center for Sustainable Agriculture. Retrieved from http://www.leopold.iastate.edu/ sites/default/files/pubs-and-papers/2011-06-foodfuel-and-freeways-iowa-perspective-how-far-foodtravels-fuel-usage-and-greenhouse-gasemissions.pdf

Schmidt, M. C., Kolodinsky, J. M., DeSisto, T. P., \& Conte, F. C. (2011). Increasing farm income and local food access: A case study of a collaborative aggregation, marketing, and distribution strategy that links farmers to markets. Journal of Agriculture, Food Systems, and Community Development, 1(4), 157175.

http://dx.doi.org/10.5304/jafscd.2011.014.017

Sharma, A., Gregoire, M. B., \& Strohbehn, C. H. (2008). Assessing costs of using local foods in independent restaurants. Journal of Foodservice Business Research, 12(1), 55-71. http://dx.doi.org/10.1080/15378020802672089

Sharma, A., \& Strohbehn, C. H. (2006). Local food connections: Economic impact of use in restaurants (PM 1853e). Ames, Iowa: Iowa State University Extension.

Shepherd, R., \& Raats, M. (2006). The psychology of food choice. Wallingford, UK: CABI. http://dx.doi.org/10.1079/9780851990323.0000

Starr, A., Card, A., Benepe, C., Auld, G., Lamm, D., Smith, K., \& Wilken, K. (2003). Sustaining local agriculture: Barriers and opportunities to direct marketing between farms and restaurants in Colorado. Agriculture and Human Values, 20(3), 301321. Retrieved from: http://dx.doi.org/10.1023/A:1026169122326

Strohbehn, C. H., \& Gregoire, M. B. (2003). Case studies of local food purchasing by central Iowa restaurants and institutions. Foodservice Research International, 14(1), 53. http://dx.doi.org/10.1111/ j.1745-4506.2003.tb00177.x 
Strohbehn, C. H., \& Gregoire, M. B. (2005). Local foods: From farm to college and university food service. The Journal of Foodservice Management and Education, 1, 1-20. Retrieved from http://www.fsmec.org/journal 2005.html

Strohbehn, C. H., \& Ortiz, A. (2011). Restaurant return on investment of local food purchases (PM 1853F). Ames, Iowa: Iowa State University Extension and Outreach. Retrieved from: http://www.iastatelocal foods.org

Sustainable Agriculture Research and Education [SARE]. (2008). Sales to restaurants and institutions. Retrieved from: http://www.sare.org/ Learning-Center/Bulletins/National-SAREBulletins/Marketing-Strategies-for-Farmers-andRanchers/Text-Version/Sales-to-Restaurants-andInstitutions

Telfer, D. J., \& Wall, G. (1996). Linkages between tourism and food production. Annals of Tourism Research, 23(3), 635-653. http://dx.doi.org/10.1016/0160-7383(95)00087-9

Thomson, J. S., Radhakrishna, R. B., Maretzki, A., \& Inciong, L. (2006). Strengthening community engagement toward sustainable local food system. Journal of Extension, 44(4), Article 4FEA2. Retrieved from http://www.joe.org/joe/2006december/rb3.shtml Tregear, A., \& Ness, M. (2005). Discriminant analysis of consumer interest in buying locally produced foods. Journal of Marketing Management, 21(1-2), 19-35.

Retrieved from http://dx.doi.org/10.1362/0267257053166811
United States Department of Agriculture [USDA], Agricultural Marketing Service. (2009). Farmers market growth: 1994-2009. Retrieved from http://www.ams.usda.gov/AMSv1.0/ams.fetch TemplateData.do? template $=$ TemplateS\&navID $=$ WholesaleandFarmersMarkets\&leftNav $=$ Wholesale andFarmersMarkets\&page $=$ WFMFarmersMarket Growth\&description $=$ Farmers $\% 20$ Market $\% 20$ Growth\&acct=frmrdirmkt

United States Department of Agriculture [USDA], National Agricultural Library. (2007). Community Supported Agriculture. Retrieved from http://www.nal.usda.gov/afsic/pubs/csa/ csa.shtml

United States Department of Agriculture (USDA). (2009). USD A launches "Know Your Farmer, Know Your Food" initiative (News Release No. 0440.09). Retrieved from http://www.usda.gov/wps/ portal/!ut/p/s.7 0 A/7 0 1OB?contentidonly= true\&contentid $=2009 / 09 / 0440 . x m l$

Wilkins, J. L., Bowdish, E., \& Sobal, J. (2000). University student perceptions of seasonal and local foods. Journal of Nutrition Education, 32(5), 261-268. http://dx.doi.org/10.1016/S0022-3182(00)70574-7

Wright, B. (2005). Selling directly to restaurants. University of Wisconsin Cooperative Extension, A3811-5. Retrieved from http://www.mosesorganic.org/attachments/ productioninfo/uwrestaurants.pdf Zepeda, L., \& Leviten-Reid, C. (2004). Consumers' views on local food. Journal of Food Distribution Research, 35(3), 1-6. Retrieved from: http://purl.umn.edu/27554 